\title{
OPTIMIZATION OF FIXED BED DOWNDRAFT REACTOR FOR RICE HUSK BIOMASS GASIFICATION USING SECONDARY AIR INTAKE VARIATION
}

\author{
F.R. Gibran ${ }^{1}$, A. Surjosatyo ${ }^{1 *}$, A.A. Hermawan ${ }^{1}$, H. Dafiqurrohman ${ }^{1}$, M.B. Anggriawan ${ }^{1}$, \\ N.R. Yusuf ${ }^{1}$, S. Maarif ${ }^{2}$ \\ ${ }^{1}$ Department of Mechanical Engineering, Faculty of Engineering, Universitas Indonesia, Kampus UI \\ Depok, Depok 16424, Indonesia \\ ${ }^{2}$ Department of Mechanical Engineering, Faculty of Engineering, Universitas Pancasila, Jakarta 12630, \\ Indonesia
}

(Received: December 2017 / Revised: January 2018 / Accepted: March 2018)

\begin{abstract}
Rice husk is one of the most abundant agricultural wastes in Indonesia, with an annual potency of 13,662 MWe. Using biomass gasification, it can be converted into producer gas, whose energy can be used for thermal and electrical power generation. In gasification terms, gas quality can be interpreted by tar content and gas energy. An experiment using an open top fixed bed downdraft gasifier (batch system) with double stage air supply was conducted by varying the secondary air injection position $(\mathrm{Z})$ and the air ratio (AR). Tar content can be represented by flaming pyrolysis duration and gas quality by the combustion energy of the gas. Flaming pyrolysis is a phenomenon which occurs inside the reactor, where tar produced is re-cracked and dissolved into smaller compounds. This can be achieved if the pyrolysis zone temperature ranges between 500 and $800^{\circ} \mathrm{C}$. With an $\mathrm{AR}$ of $80 \%$, at $\mathrm{Z}=38 \mathrm{~cm}$, flaming pyrolysis with the longest duration of 400 seconds was created, which indicated that this condition had the lowest tar content; meanwhile, at $\mathrm{Z}=50 \mathrm{~cm}$, gas with the highest energy $(734.64 \mathrm{~kJ})$ was obtained.
\end{abstract}

Keywords: Air ratio; Biomass gasification; Flaming pyrolysis; Pyrolysis zone optimization; Secondary air gasification

\section{INTRODUCTION}

Rice husk is one of the agricultural wastes in Indonesia with the largest annual potency (21,114,074 tons/year), equal to 13,662 MWe of electrical power (ESDM, 2013). One of the common methods to harness its energy is biomass gasification. This is a thermochemical process to convert solid biomass (rice husk) into synthetic gas, which can then be used for thermal and electrical power generation (Basu, 2010). However, utilizing its energy means that the gas quality has to meet certain standards. In gasification terms, these standards can be interpreted as tar content and gas energy. They are important, especially for power generation, when most engines cannot operate if certain amounts of tar are contained in the gas. Tar is a residue in the gasification process; it is a brownish-black liquid poly-aromatic hydrocarbon, which presents in a spray form carried away by the gas. Gas with high tar content usually damages engines, pollutes the environment, and lowers gas energy. Consequently, methods for tar reduction in syngas (synthetic gas) have become one of the most important topics in biomass gasification research (Yoon et al., 2012).

\footnotetext{
*Corresponding author's email: adisur@eng.ui.ac.id, Tel. +62-81-11928465, Fax. +62-21-7270033 Permalink/DOI: https://dx.doi.org/10.14716/ijtech.v9i2.1081
} 
Gasification consists of four thermochemical processes: oxidation, reduction, pyrolysis and drying (Basu, 2010). In this paper, the pyrolysis process is highlighted because of its role in producing tar, waste that can be harmful to the environment and the gasification equipment itself. Moreover, tar can be destroyed by increasing the pyrolysis temperature in order to create a phenomenon called Thermal Tar Cracking. Thus, optimizing the pyrolysis zone could be a promising way to reduce tar content. The tar content in the gasification process should be below $5 \mathrm{mg} / \mathrm{Nm}^{3}$ (Basu, 2010). Research conducted in this field includes: (1) An experiment using coconut shell, wood and rice husk which produced a pyrolysis temperature of $103.97-141.64^{\circ} \mathrm{C}$ (Wicaksono, 2013); (2) Grate modification and stirrer and overflow addition, which created a pyrolysis temperature of $614.56^{\circ} \mathrm{C}$ using rice husk as the biomass fuel (Achiruddin, 2014); and (3) Appropriate ER selection, which produced an optimal pyrolysis zone with a stable temperature $\left(500-600^{\circ} \mathrm{C}\right)$ for an operating time of 60 minutes (Dafiqurrohman et al., 2016).

One way to optimize the pyrolysis zone is to add more air supply stage to the reactor. Furthermore, in this paper a small scale downdraft gasification reactor fueled by rice husk was installed with a double air supply. The downdraft type was chosen because of its efficiency to reduce tar and because air supply is implemented to achieve a higher temperature in the pyrolysis zone. The addition varied from secondary to tertiary air (Galindo et al., 2014; Guo et al., 2014). By appropriate Air Ratio (AR) selection, air could be transferred into the pyrolysis zone so that flaming pyrolysis could be achieved. Consequently, more heat was used to crack the tar and its content inside the syngas was able to be reduced to the lowest level possible (Martinez et al., 2011).

Several researches have been conducted in relation to this topic, with the following findings.

Table 1 State of the art

\begin{tabular}{|c|c|c|}
\hline No & Author & State of the art \\
\hline 1 & Phuphuakrat et al., 2010 & Increase in ER decreased the tar mass. \\
\hline 2 & Jaojaruek at al., 2011 & $\begin{array}{l}\text { Secondary air addition reduced tar content } 91 \% \text {, increased HHV } \\
19.25 \% \text { and increased combustible gas content } 25.9 \% \text {. }\end{array}$ \\
\hline 3 & Martinez et al., 2011 & Reaction modification to multistage type increased syngas energy. \\
\hline 4 & Ma et al., 2012 & $\begin{array}{l}3 \text { hours experiment showed that the production trends of } \mathrm{CO} \text { and } \\
\mathrm{H}_{2} \text { were inversely proportional to that of } \mathrm{CO}_{2} .\end{array}$ \\
\hline 5 & Blasi \& Branca, 2013 & $\begin{array}{l}\text { The higher the AR, the lower the tar content. The lowest tar } \\
\text { content was achieved at } \mathrm{Z} / \mathrm{L} \text { value range of } 0.6-0.65 \text {. }\end{array}$ \\
\hline 6 & Guo et al., 2014 & $\begin{array}{l}\text { ER selection was depended on requirements. To produce the } \\
\text { lowest tar content, the ER value was } 0.32 \text { while to generate the } \\
\text { highest gasification efficiency and gas energy levels, the ER value } \\
\text { range was } 0.25-0.27 \text {. }\end{array}$ \\
\hline 7 & Galindo et al., 2014 & $\begin{array}{l}\text { With a supply air debit of } 20 \mathrm{Nm}^{3} / \mathrm{h} \text { and ratio of } 80 \% \text {, syngas with } \\
87 \% \text { tar content reduction was obtained. }\end{array}$ \\
\hline 8 & Khonde \& Chaurasia, 2016 & $\begin{array}{l}\text { Simulation and experimental results showed the same conclusion, } \\
\text { the higher the temperature, the lower the tar content. }\end{array}$ \\
\hline
\end{tabular}

Based on these references, the research objective of this work is to find the optimum Air Ratio (AR) between the secondary and primary air supplies, and the optimum height (Z) of secondary air intake to produce syngas with the highest energy and lowest tar content. 


\section{METHODS}

The components and apparatus used are shown in Figure 1, where (a) is the reactor, where the solid biomass was gasified; (b) the blower, which consisted of two air blowers and one suction blower to pull up the gas; (c) the air intake, as the air supply entrance inside the reactor. This consisted of primary and secondary channels, and the flow rate of the air supply was measured by the orifice meter; (d) the thermocouple inside the reactor and burner; (e) the filtering system, consisting of the cyclone and storage tank; (f) the burner to test the gas quality; and (g) the data logger and user interface.
(a) Reactor
(b) Blower
(d) Thermocouples
(c) Primary and Secondary Air Intake
(e) Filtering System
(g) Data Logger

(d)

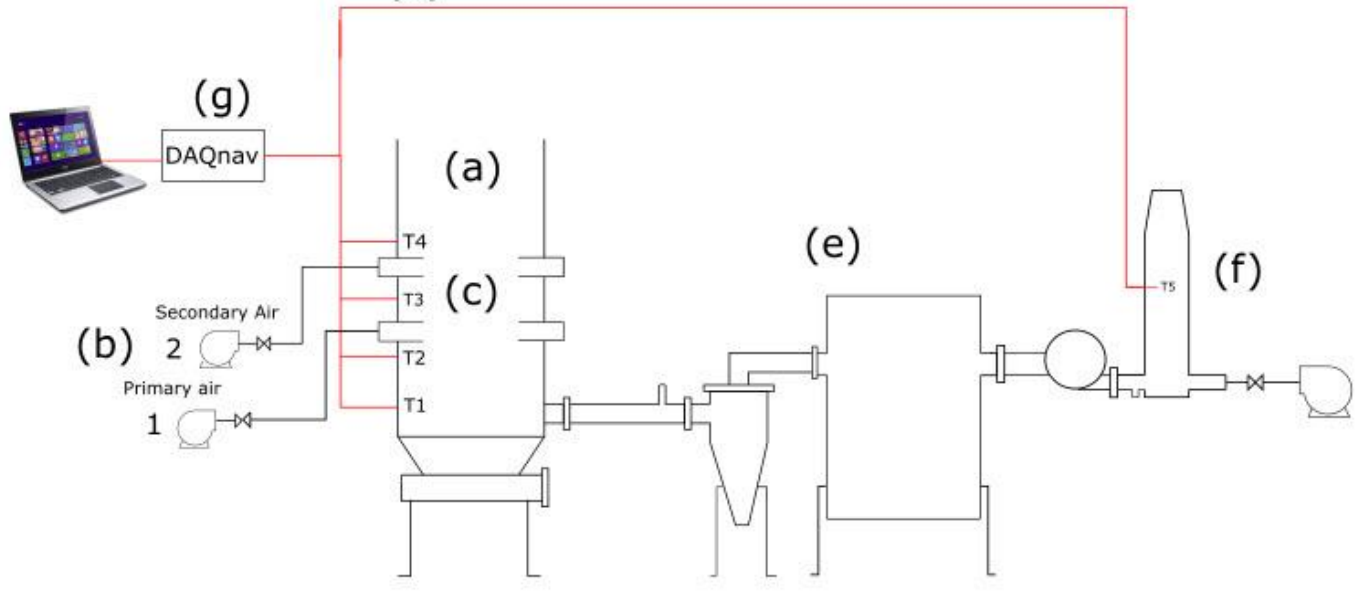

Figure 1 Schematic diagram of the experiment

The experimental procedures consisted of several processes, namely (i) Reactor ignition with DEX fuel and sheet of paper; (ii) Air supply settings for primary air of $30^{\circ}, 45^{\circ}, 60^{\circ}$ and $75^{\circ}$, opening and secondary with ARs of 40, 50, 60 and 80\%; (iii) Injection position of secondary air settings inside the reactor $(Z)$ with variations of $34,38,42,46$ and $50 \mathrm{~cm}$ measured from the top of the reactor (iv) Suction of syngas by the suction blower (v) When the gas became cream colored, the burner was ready for ignition using the torch; (vi) Air supply settings for the burner; and (vii) Continuous feeding until the flame in the burner went out.

The experiment results were raw data; that is, (a) Rice husk mass from spring scale measurement; (b) Temperature distribution along the burner and the reactor; and (c) Pressure differences in air blown from the orifice meter. The temperature data was processed into a graph using Microsoft Excel software. The other data was processed into gasification parameters using several equations:

$$
\begin{gathered}
m_{\text {air }}=\rho C_{d} A_{2} \sqrt{\frac{2\left(P_{1}-P_{2}\right)}{\rho\left(1-\beta^{4}\right)}} \quad\left(\frac{\mathrm{kg}}{\mathrm{s}}\right) \\
A F R_{\text {act }}=\frac{m_{\text {air }}}{m_{\text {fuel }}} \\
\text { AFRst }=0.0889(C+0.375 S)+0.265 H-0.03330
\end{gathered}
$$

Equation 3 was obtained from (Martinez, 2011), and C, S, H, O from Dafiqurrohman et al. (2016). 


$$
E R=\frac{A F R_{a c t}}{A F R_{s t}}
$$

The calculation of gas enthalpy was obtained from Fakhim \& Farhanieh (2011), Sun et al. (2009) and Zhao (2012).

$$
\overline{C_{p}}(T)=A+B T+C T^{2}+D T^{3} \quad\left(\frac{k J}{k m o l K}\right)
$$

A, B, C, D are coefficients obtained from Jarungthammachote \& Dutta (2007).

$$
\begin{gathered}
\Delta \overline{h_{T}}=\int_{298,15}^{T} \overline{C_{p}}(T) d T \quad\left(\frac{k J}{k m o l}\right) \\
\dot{n}=\dot{m}_{f u e l} \times n_{m} \quad\left(\frac{m o l}{s}\right) \\
\dot{H}=\sum_{i=\text { product }} n_{i}\left(\overline{h_{f, l}^{0}}+\Delta \overline{h_{T, l}}\right) \quad\left(\frac{k J}{s}\right)
\end{gathered}
$$

$\mathrm{H}$ is gas energy obtained from the integral of combustion enthalpy vs the time curve.

\section{RESULTS AND DISCUSSION}

\subsection{Analysis of Primary Air Experiment}

The experiments were conducted by varying the primary air valve, with $30^{\circ}, 45^{\circ}, 60^{\circ}$ and $75^{\circ}$ openings. The optimum condition was determined by flaming pyrolysis and gas energy.

The first valve setting $\left(30^{\circ}\right)$ did not produce a significant result; no combustion took place inside the reactor due to the lack of oxygen (air) supply.

At the valve opening of $45^{\circ}$, as seen in Figure $3 \mathrm{a}$, the pyrolysis temperature reached the range for flaming pyrolysis $\left(500-800^{\circ} \mathrm{C}\right)$ stably for 355 seconds. As mentioned previously, the longer the duration of the flaming pyrolysis, the more tar that is cracked. The energy produced was 248.8 $\mathrm{kJ}$ (Figure 2); this was affected by the gas composition, in which $\mathrm{CO}, \mathrm{H}_{2}$ and $\mathrm{CH}_{4}$ were combustible, so contributed mainly to gas energy production while $\mathrm{CO}_{2}$ did not. The experiments conducted by Ma et al., (2012), Singh and Sekhar (2016) showed that the production of CO and $\mathrm{H}_{2}$ was inversely proportional to that of $\mathrm{CO}_{2}$. This was due to the reactions in the reduction zone; i.e. Boudouard and water gas reactions, which absorbed heat from the oxidation zone so that their temperatures increased (Zainal, 2002). Since both reactions were endothermic, a rise in temperature would cause the reaction equilibrium to shift to the right (Law, 2009), so that the level of $\mathrm{CO}_{2}$ as a reactant decreased, and more $\mathrm{CO}$ and $\mathrm{H}_{2}$ were produced. Therefore, gas energy increased (Guo et al., 2014; Singh \& Sekhar, 2016).

At a valve opening of $60^{\circ}$, the results show a high value of oxidation (up to $1200^{\circ} \mathrm{C}$ ) and reduction temperature (up to $800^{\circ} \mathrm{C}$ ). These indicate a high content of $\mathrm{CO}$ and $\mathrm{H}_{2}$ in the gas. This assumption was proven by the gas energy calculation, i.e. $306.1 \mathrm{~kJ}$ (Figure 2). This value indicates that more air was blown to the oxidation zone, so its temperature rose and less air was supplied to the pyrolysis zone, meaning that flaming pyrolysis could not be achieved. Thus, it can be concluded that more tar was produced with the $60^{\circ}$ opening than the $45^{\circ}$ one.

The burner temperature reached $900^{\circ} \mathrm{C}$ (Figure $3 \mathrm{~b}$ ), while the energy value was only $212 \mathrm{~kJ}$. This indicates an unstable increase in gas energy. Oxidation reactions require oxygen as a reactant. At the $75^{\circ}$ opening, the air supply was abundant. As a result, the reaction equilibrium shifted to the right (Law, 2009), so tmore $\mathrm{CO}_{2}$ was produced. Subsequently, $\mathrm{CO}_{2}$ gas will react with carbon 
$\left(\mathrm{CO}_{2}\right.$ reduced) endothermically in a Boudouard reaction, producing $\mathrm{CO}$. As considerable $\mathrm{CO}_{2}$ was produced at the beginning of the oxidation phase, more $\mathrm{CO}$ was generated, so gas energy increased spontaneously. Meanwhile, as oxidation continued, the amount of $\mathrm{CO}_{2}$ was so abundant that the energy required to supply the Boudouard reaction was insufficient to reduce all the $\mathrm{CO}_{2}$. Thus, much of the $\mathrm{CO}_{2}$ gas was not reduced, so its presence in gas decreased the gas energy.

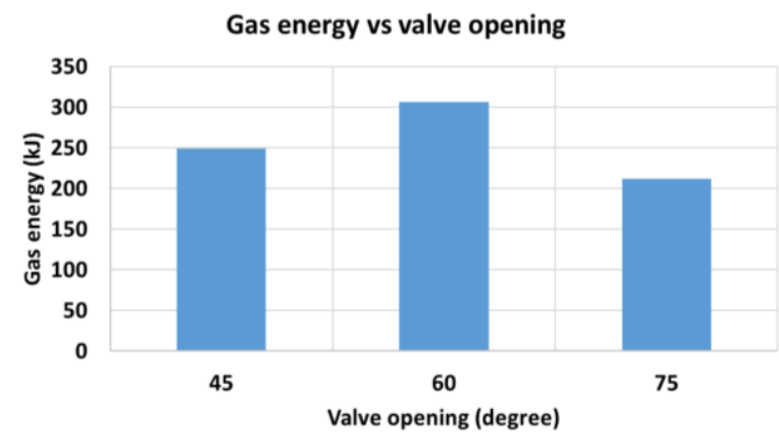

(a)

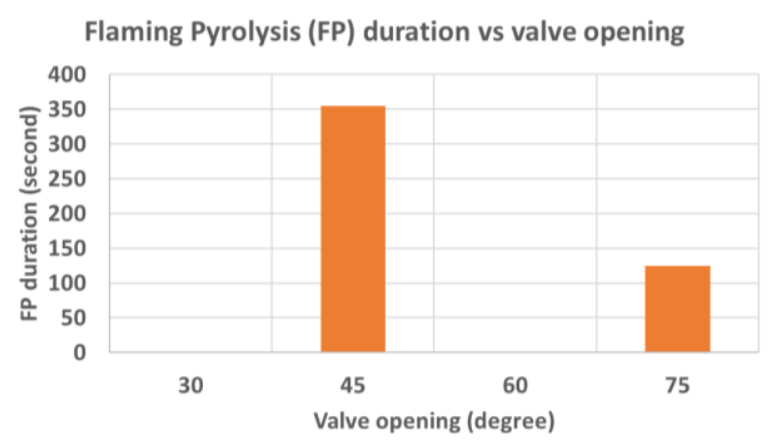

(b)

Figure 2 Gas energy (a) and flaming pyrolysis duration (b) vs valve opening

By comparing the four variations, based on their flaming pyrolysis stability, the $45^{\circ}$ valve opening was chosen as the optimum one and set as a fixed variable for following experiments.

\subsection{Analysis of Secondary Air Experiment}

The objective was to determine the optimum secondary air injection position $(Z)$ and Air Ratio (AR). The $Z$ value varied from $34 \mathrm{~cm}$ to $50 \mathrm{~cm}$, with $4 \mathrm{~cm}$ intervals, and for each $Z$, four varying secondary air valve openings were used, i.e. $30^{\circ}, 35^{\circ}, 40^{\circ}$ and $45^{\circ}$, producing ARs of $40 \%, 50 \%$, $60 \%$ and $80 \%$.

At $\mathrm{Z}=34 \mathrm{~cm}$, all the AR variations failed to achieve flaming pyrolysis (Figure 6), so tar cracking was poor. Moreover, at AR $60 \%$ and $80 \%$, both gas energies were very similar, due to the similar temperature range in the oxidation zone. Meanwhile, for AR $40 \%$ to $60 \%$, the gas energy increased significantly due to the higher supply of air.

At $\mathrm{Z}=38 \mathrm{~cm}$, the pyrolysis temperature reached the requirement for flaming pyrolysis duration unstably (Figure 4), for 390 seconds (Figure 6). This enabled long tar cracking, which produced gas with low tar content (Morf, 2001; Zhai, 2015). To validate this, a new parameter, Z/L, a comparison between the secondary air injection position $(\mathrm{Z})$ and reactor height $(\mathrm{L})$, was needed. With $\mathrm{L}=60 \mathrm{~cm}$, the $\mathrm{Z} / \mathrm{L}$ value was 0.633 . Another experiment conducted by Blasi and Branca (2013) succeeded in correlating $\mathrm{Z}$ with tar content at AR 80\%. The lowest tar content achieved at $\mathrm{Z}=0.3-0.32 \mathrm{~m}$. With $\mathrm{L}=0.5 \mathrm{~m}$, the $\mathrm{Z} / \mathrm{L}$ value of the Blasi experiment was $0.6-0.65$. The $\mathrm{Z} / \mathrm{L}$ obtained from this experiment was 0.633, which was in the Blasi experiment range.

In Figure 5, at $Z=38 \mathrm{~cm}$, the gas energy rose from $\mathrm{AR} 40 \%$ to $50 \%$ but increased from $60 \%$ to $80 \%$. This was due to the flaming pyrolysis which occurred in AR $60 \%$ and $80 \%$. During the flaming pyrolysis, some air from the oxidation zone moved towards the pyrolysis zone. Thus, the amount of air in the oxidation zone decreased, resulting in lower oxidation energy. Moreover, since oxidation transferred energy to the reduction process, lower oxidation energy led to lower energy transfer. As the reduction zone serves as a syngas producer, lower energy resulted in less syngas $\left(\mathrm{CO}\right.$ and $\left.\mathrm{H}_{2}\right)$ being produced (lower syngas energy).

At $\mathrm{Z}=42 \mathrm{~cm}$, flaming pyrolysis did not occur at AR 80\% (Figure 6) because the abundant supply of air $\left(\mathrm{O}_{2}\right)$ made the reaction equilibrium shift to the right (Law, 2009). As a result, more reaction products were generated and more $\mathrm{O}_{2}$ (reactant) was needed to fulfil this condition. Thus, more air flowed to the oxidation zone, so the amount of air for pyrolysis was small and flaming 
pyrolysis could not be achieved. Meanwhile, at AR 50\% and 60\%, the appropriate amount of air ratio meant that oxidation did not occur rapidly, so some air supply was able to flow into the pyrolysis zone and flaming pyrolysis was achieved.

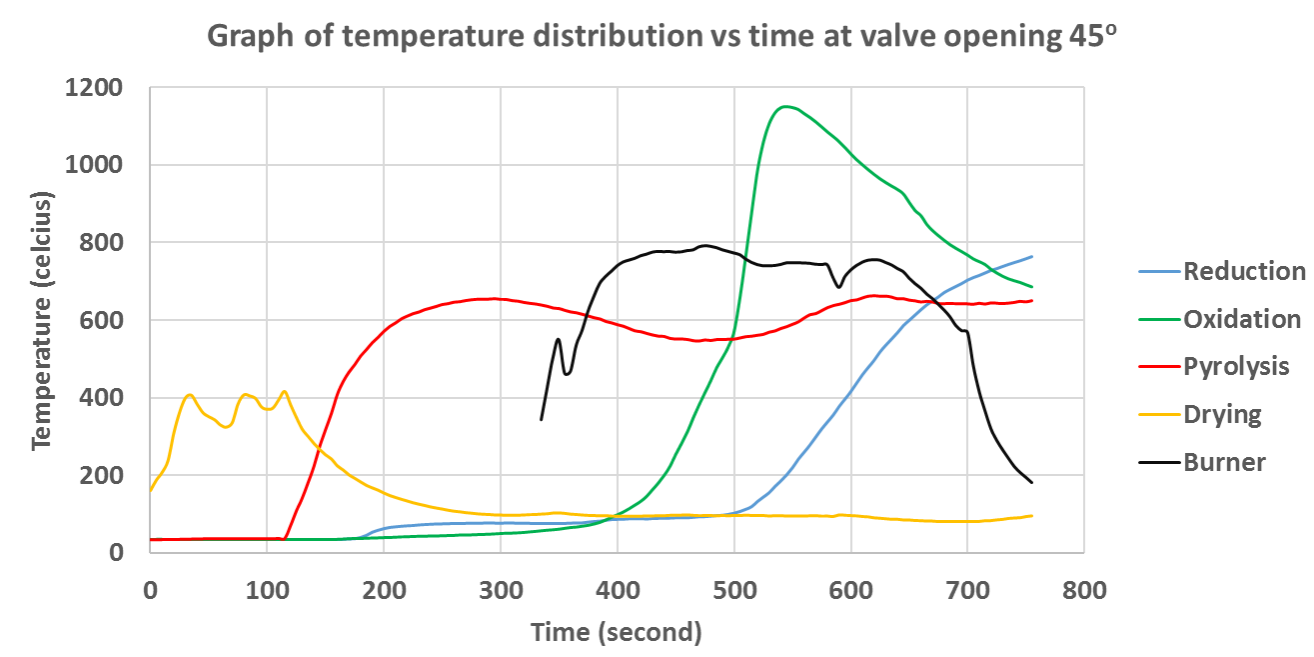

(a)

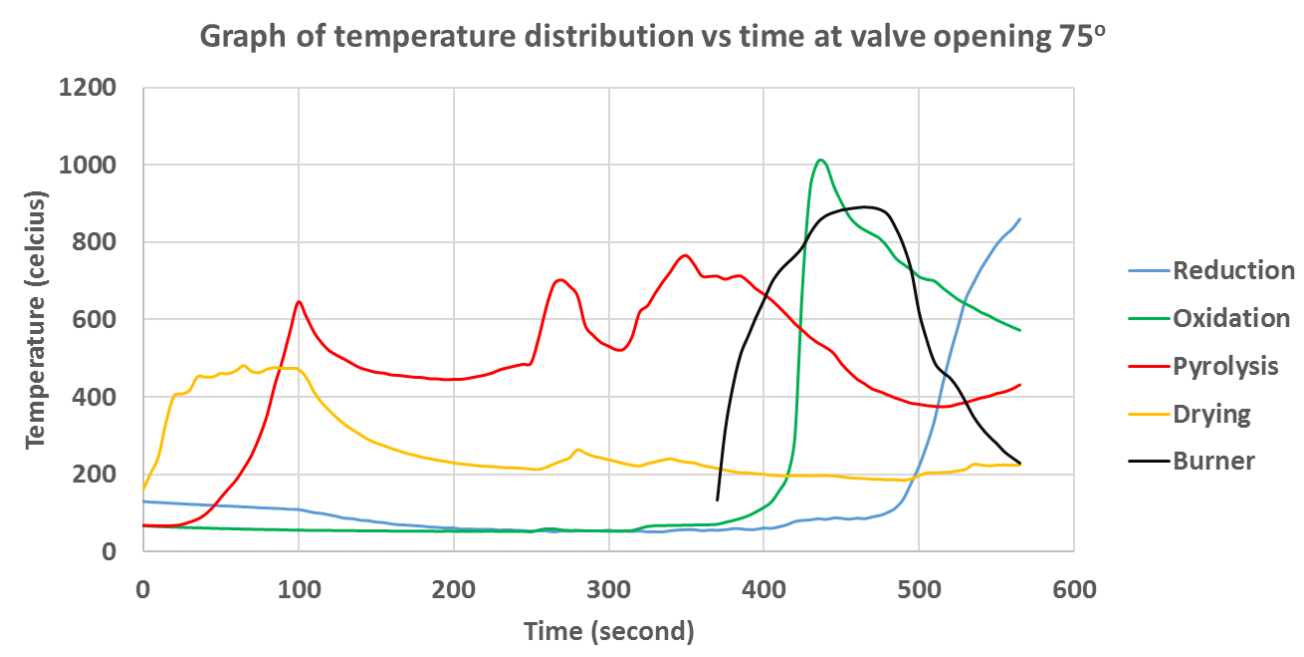

(b)

Figure 3 Temperature distribution vs operational time at valve openings of: (a) $45^{\circ}$; and (b) $75^{\circ}$

In this condition, as AR increased, the gas energy also rose. This result matches the Blasi experiment (Blasi \& Branca, 2013), which compared the gas composition at AR 50\% and $80 \%$. With the same $\mathrm{Z} / \mathrm{L}$ value, i.e. $0.7(\mathrm{Z}=0.35 \mathrm{~m}$ in the Blasi experiment), at $\mathrm{AR} 50 \%$, the compositions of $\mathrm{CO}, \mathrm{H}_{2}, \mathrm{CO}_{2}$ and $\mathrm{CH}_{4}$ were $18 \%, 15 \%, 12 \%$ and $3 \%$ respectively, while at AR $80 \%$, the compositions were $25 \%, 15 \%, 7 \%$ and $2.5 \%$. It was stated earlier that the CO content was proportional to gas energy, while for $\mathrm{CO}_{2}$ it was the opposite (Guo et al., 2014; Singh \& Sekhar, 2016). So, based on the $\mathrm{CO}$ and $\mathrm{CO}_{2}$ content, AR $80 \%$ had more energy than AR 50\%.

At $Z=46 \mathrm{~cm}$, when $A R=80 \%$, the injection of secondary air was parallel to that of primary air, so the air was concentrated only in the oxidation zone. This air shifted the reaction equilibrium to the right, which made the product dominate the reaction. To keep the reaction balance, more $\mathrm{O}_{2}$ was needed in the oxidation zone so that less air would be supplied for pyrolysis. Meanwhile, at $\mathrm{AR} 40 \%, 50 \%$ and $60 \%$, flaming pyrolysis occurred due to the correct air ratios. The longest pyrolysis duration was achieved at AR 50\%, i.e. 195 seconds (Figure 6). 


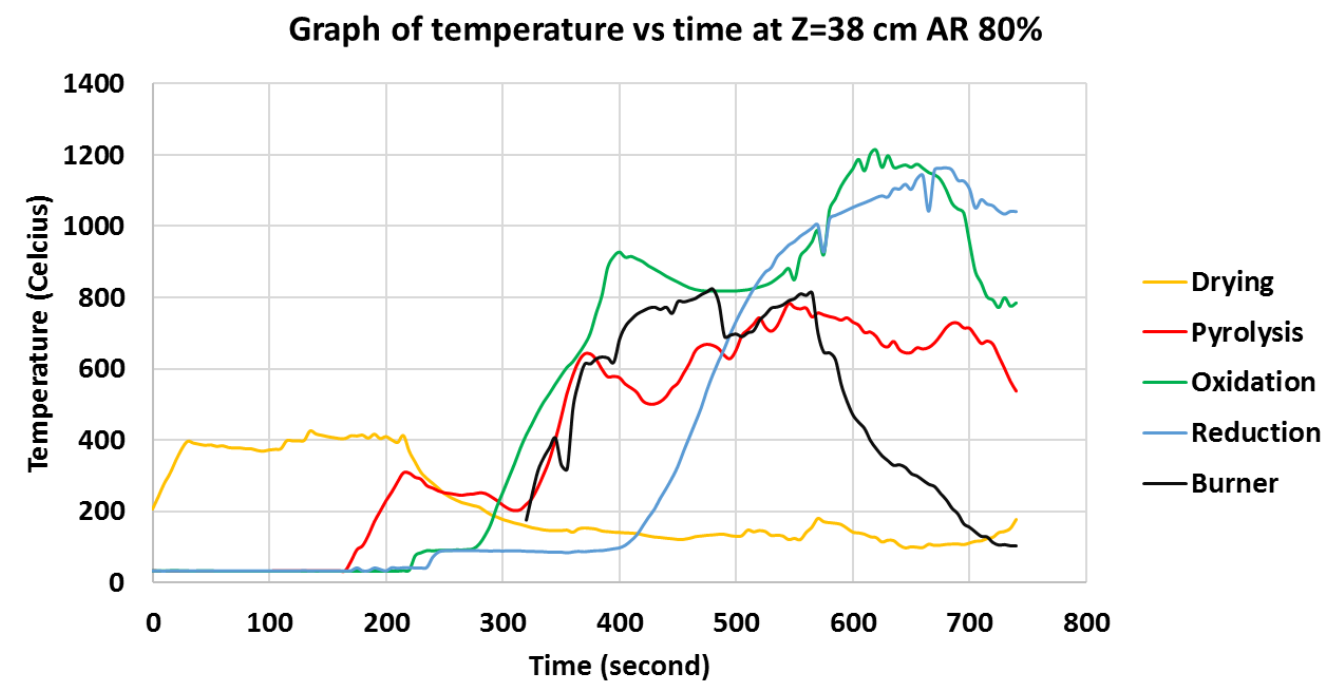

Figure 4 Graph of temperature vs time at $Z=38 \mathrm{~cm}$ AR $80 \%$

The AR value increased with gas energy. This result agreed with the Blasi experiment (Blasi \& Branca, 2013), which compared the gas composition at AR 50\% and $80 \%$. At $\mathrm{Z}=38 \mathrm{~cm}$ in the Blasi experiment $(\mathrm{Z} / \mathrm{L}=0.77)$, with $\mathrm{AR} 50 \%$, the compositions of $\mathrm{CO}, \mathrm{H}_{2}, \mathrm{CO}_{2}$ and $\mathrm{CH}_{4}$ were $19 \%, 16 \%, 12 \%$ and $3 \%$, respectively, while at AR $80 \%$, the compositions were $25 \%, 15 \%, 7 \%$ and $2.5 \%$. As $\mathrm{CO}$ content is proportional to gas energy, while for $\mathrm{CO}_{2}$ the opposite is the case (Guo, 2014; Singh, 2016), it can be concluded that AR 80\% produced higher energy than AR $50 \%$.

At $\mathrm{Z}=50 \mathrm{~cm}$, the gas energy trend was the same as that of $\mathrm{Z} 42$ and $46 \mathrm{~cm}$, which was proportional with AR (Figure 3). The Blasi experiment (Blasi \& Branca, 2013), which compared the gas composition at AR 50\% and $80 \%$, produced the same result.

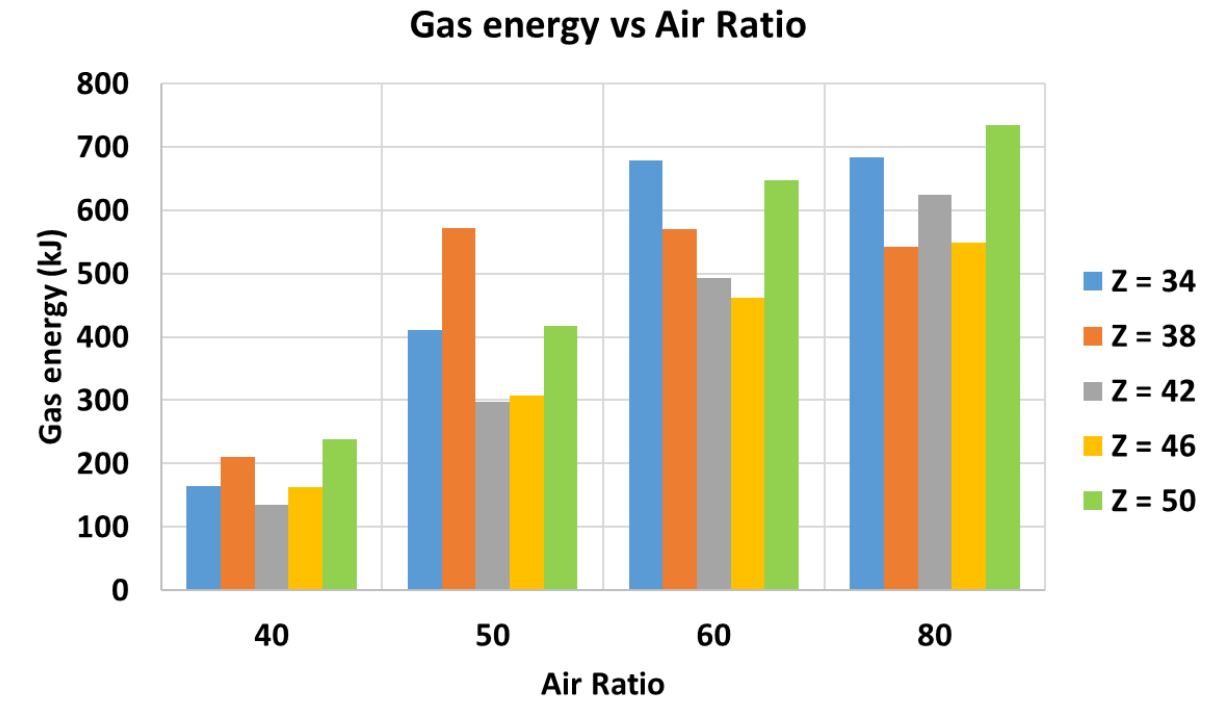

Figure 5 Gas energy vs Air Ratio (AR) for each Z variation

With the same $\mathrm{Z} / \mathrm{L}$ value, i.e. 0.83 ( $\mathrm{Z}=0.42 \mathrm{~m}$ in the Blasi experiment), at $\mathrm{AR} 50 \%$, the compositions of $\mathrm{CO}, \mathrm{H}_{2}, \mathrm{CO}_{2}$ and $\mathrm{CH}_{4}$ were $19 \%, 17 \%, 12 \%$ and $3 \%$ respectively, while at AR $80 \%$ they were $25 \%, 15 \%, 7 \%$ and $2.5 \%$. The more the $\mathrm{CO}$, and the less the $\mathrm{CO}_{2}$ produced, the higher the gas energy (Guo et al., 2014; Singh \& Sekhar, 2016). It can therefore be concluded that AR $80 \%$ produced more energy than AR 50\%. 
The secondary air was injected below the primary air so that it was concentrated in the lower part of the oxidation zone. When the AR was $80 \%$, the amount of concentrated air was large. This caused the reaction equilibrium to shift, so that more $\mathrm{O}_{2}$ was needed for oxidation. Thus, the amount of air supplied for pyrolysis was small and unable to create flaming pyrolysis. At AR $40 \%, 50 \%$ and $60 \%$, flaming pyrolysis occurred due to the correct AR selection.

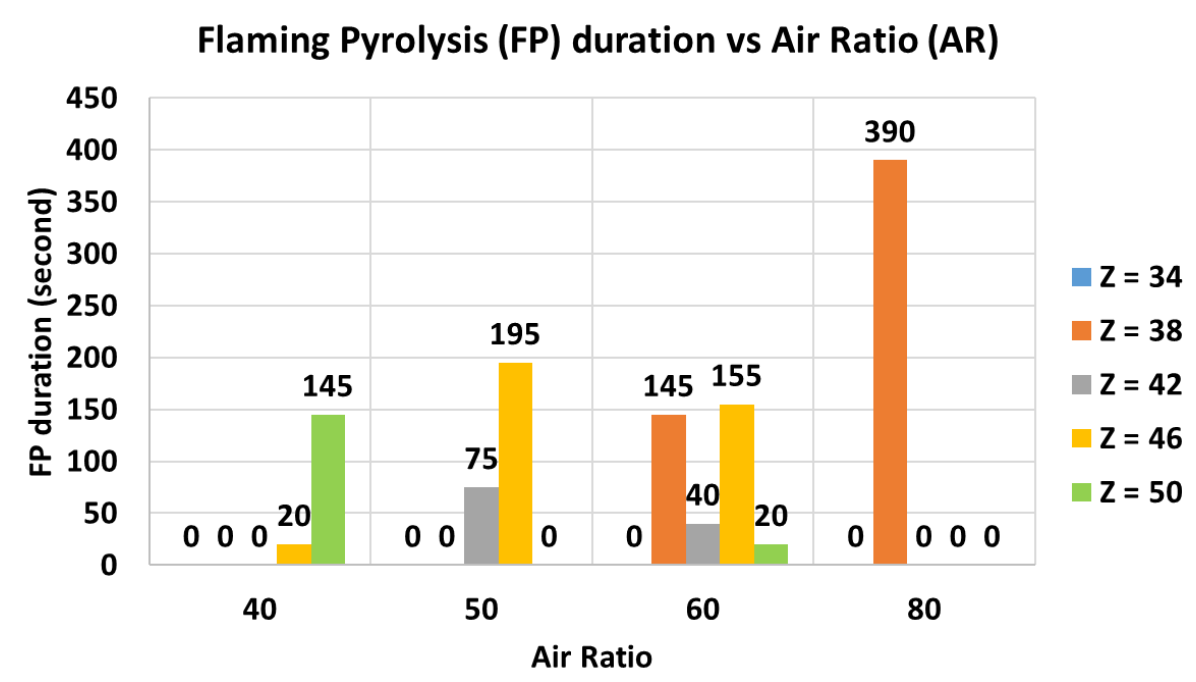

Figure 6 Flaming pyrolysis duration vs Air Ratio (AR) for each Z variation

Compared to the others, the $\mathrm{Z}=50 \mathrm{~cm}$ at $\mathrm{AR} 80 \%$ condition produced the highest gas energy, i.e. $734.64 \mathrm{~kJ}$ (Figure 5). At this position $(Z=50 \mathrm{~cm}$ ), secondary air was supplied to the lower region of the oxidation zone, which was close to the reduction zone. As a result, energy transfer from oxidation to the reduction zone was relatively more efficient. This accelerated the production of $\mathrm{CO}$ and $\mathrm{H}_{2}$ in reduction zone, which subsequently increased the syngas energy. The air ratio (AR) and injection position (Z) were clearly interrelated parameters. As shown in Figure 6 , at the highest AR value (80\%), in most $Z$, flaming pyrolysis could not be achieved. This was due to the chemical equilibrium of the gasification reactions, in which more air would make the reaction more consumptive; in other words, the more air that was supplied, the higher its demand. In this experiment, the air was attracted to the oxidation zone since it served as the reactant. As the reaction this zone became more consumptive, more air would flow to it and less would go to the pyrolysis zone, meaning it was unable to achieve the flaming pyrolysis condition. However, an anomaly was found in $\mathrm{Z}=38 \mathrm{~cm}$, where the highest flaming pyrolysis duration occurred. This was because at this position the secondary air was directly injected into the pyrolysis zone, making it easier to achieve flaming pyrolysis. This result showed the importance of $\mathrm{Z}$ in the secondary air gasification reactor.

\section{CONCLUSION}

The optimum Air Ratio (AR) of the secondary air stage gasifier was $80 \%$, at which the longest flaming pyrolysis was achieved and the highest combustion (gas) energy was obtained. The optimum pyrolysis zone was achieved at AR $80 \%$ with $\mathrm{Z}=38 \mathrm{~cm}$, with the longest duration of flaming pyrolysis of 390 seconds. In this condition, the $\mathrm{Z} / \mathrm{L}$ was 0.633 , which agreed with the Blasi experiment range, i.e. 0.6-0.65. The highest gas energy was $734.64 \mathrm{~kJ}$, achieved at AR $80 \%$ $Z=50 \mathrm{~cm}$. For the $Z$ values of $34 \mathrm{~cm}, 42 \mathrm{~cm}, 46 \mathrm{~cm}$ and $50 \mathrm{~cm}$, as the AR increased, gas energy also rose. As AR became higher, due to the reaction equilibrium, more air would flow to the oxidation zone rather than the pyrolysis zone. As a result, more energy was transferred to the reduction zone to produce $\mathrm{CO}$ and $\mathrm{H}_{2}$, resulting in higher gas energy. At $\mathrm{Z}=38 \mathrm{~cm}$, the maximum gas energy was achieved at AR 50\%, when no flaming pyrolysis occurred, and decreased 
gradually from AR $60 \%$ to $80 \%$, which both produced flaming pyrolysis. This was because the secondary air was injected directly into the pyrolysis zone $(Z=38 \mathrm{~cm})$ so that more of this air would be used for creating flaming pyrolysis, rather than being supplied to the oxidation zone. In this position, the greater the quantity of air (higher AR), the more stable the flaming pyrolysis. The addition of secondary air increased gasification efficiency in terms of energy produced. At the $60^{\circ}$ primary air valve opening, the energy produced was $306.1 \mathrm{~kJ}$. With the same amount of air, AR $60 \%$ could produce gas with total energy more than twice as high. In most conditions, the secondary air reduced the flaming pyrolysis duration, instead of increasing it. Meanwhile, for appropriate parameter ( $\mathrm{AR}$ and $\mathrm{Z}$ ) selection, its duration could be increased slightly, as $\mathrm{Z}=38$ $\mathrm{cm}$ with AR $80 \%$ duration was 390 seconds, and primary $45^{\circ}$ was 355 seconds. This was probably due to the batch system used in the experiment. Further analysis could be made by conducting a continuous gasification system test. Finally, it is also important to notice that flaming pyrolysis only served as a representative parameter of tar content inside the produced syngas. It could not accurately reflect the amount of tar, since several different phenomena affect tar production. Therefore, the effectiveness of secondary air in reducing tar content should be validated by conducting tar measurement experimentation.

\section{ACKNOWLEDGEMENT}

The authors wish to thank the Indonesia Ministry of Research, Technology and Higher Education for funding this project with grant number 2724/UN2.R3.1/HKP05.0012017.

\section{REFERENCES}

Achiruddin, S., 2014. Biomass Gasification Study of Coconut Shell and Rice Husk. Master's Thesis. Department of Mechanical Engineering, Universitas Indonesia

ESDM (Indonesia Ministry of Energy and Mineral Resource). 2013. Indonesia Energy Outlook 2013

Basu, P., 2010. Biomass Gasification and Pyrolysis Practical Design. Academic Press Publication: Elsevier

Blasi, C., Di., Branca, C., 2013. Modeling a Stratified Downdraft Wood Gasifier with Primary and Secondary Air Entry. Fuel, Volume 104, pp. 847-860

Dafiqurrohman, H., Surjosatyo, A., Gibran, F.R., 2016. Air Intake Modification for Pyrolysis Optimization on Rice Husk Fixed Bed Downdraft Gasifier with Maximum Capacity of 30 $\mathrm{kg}$ /hour. International Journal of Technology, Volume 7(8), pp. 1352-1361

Fakhim, B., Farhanieh, F., 2011. Second Law Analysis of Bubbling Fluidized Bed Gasifier for Biomass Gasification. Progress in Biomass and Bioenergy Production, Chapter 2, pp. 22-38

Galindo, A.L., Lora, E.S., Andrade, R.V., Giraldo, S.Y., Jaen, R.L., Cobas, V.M., 2014. Biomass Gasification in a Downdraft Gasifier with a Two-stage Air Supply: Effect of Operating Conditions on Gas Quality. Biomass and Bioenergy, Volume 61, pp 236-244

Guo, F., Dong, Y., Dong, L., Guo, C., 2014. Effect of Design and Operating Parameters on the Gasification Process of Biomass in a Downdraft Fixed Bed: An Experimental Study. International Journal of Hydrogen Energy, Volume 39(11), pp. 5625-5633

Jaojaruek, K., Jarungthammachote, S., Grauito, M.K., Wongsuwan, H., Homhual, S., 2011. Experimental Study of Wood Downdraft Gasification for an Improved Producer Gas Quality through an Innovative Two-stage Air and Premixed Air/Gas Supply Approach. Bioresource Technology, Volume 102(7), pp. 4834-4840

Jarungthammachote, S., Dutta, A., 2007. Thermodynamic Equilibrium Model and Second Law Analysis of a Downdraft Waste Gasifier. Energy, Volume 32(9), pp. 1660-1669 
Khonde, R. Chaurasia, A., 2016. Rice Husk Gasification in a Two-stage Fixed-bed Gasifier: Production of Hydrogen Rich Syngas and Kinetics. International Journal of Hydrogen Energy, Volume 41(21), pp. 8793-8802

Law, C.K., 2009. Combustion Physics. Cambridge University Press

Ma, Z., Zhang, Y., Zhang, Q., Qu, Y., Zhou, J., Qin, H., 2012. Design and Experimental Investigation of a $190 \mathrm{kWe}$ Biomass Fixed Bed Gasification and Polygeneration Pilot Plant using a Double Air Stage Downdraft Approach. Energy. Volume 46(1), pp. 140-147

Martinez, J.D., Lora, E.E.S., Andrade, R.V., Jaen, R.L., 2011. Experimental Study on Biomass Gasification in a Double Air Stage Downdraft Reactor. Biomass and Bioenergy, Volume 35(8), pp. 3465-3480

Morf, P.O., 2001. Secondary Reactions of Tar during Thermochemical Biomass Conversion. PhD Thesis. ETH Zurich

Phuphuakrat, T., Nipattummakul, N., Namikoa, T., Kerdsuwan, S., Yoshikawa, K., 2010. Characterization of Tar Content in the Syngas Produced in a Downdraft Type Fixed Bed Gasification System from Dried Sewage Sludge. Fuel, Volume 89(9), pp. 2278-2284

Singh, V.C.J., Sekhar, J., 2016. Performance Studies on a Downdraft Biomass Gasifier with Blends of Coconut Shell and Rubber Seed Shell as Feedstock. Applied Thermal Engineering, Volume 97, pp. 22-27

Sun, S. Zhao, Y., Ling, F., Su, F., 2009. Experimental Research on Air Staged Cyclone Gasification of Rice Husk. Fuel Processing Technology, Volume 90, pp. 465-471

Wicaksono, R., 2013. Biomass Gasification of Coconut Shell, Wood, and Rice Husk. Master's Thesis. Mechanical Engineering Universitas Indonesia

Yoon, S.J., Son, Y.-I., Kim, Y.K., Lee, J.G., 2012. Gasification and Power Generation Characteristics of Rice Husk and Rice Husk Pellet using a Downdraft Fixed-bed Gasifier. Renewable Energy, Volume 42, pp. 163-167

Zainal, Z. A. Rifau, A., Quadir, G. A., Seetharamu, K. N., 2002. Experimental investigation of a downdraft biomass gasifier. Biomass and Bioenergy, Volume 23, pp. 283-289

Zhai, M., Wang, X., Zhang, Y., Dong, P., Qi, G., Huang, Y., 2015. Characteritics of rice husk tar secondary thermal cracking. Energy, Volume 93, pp. 1321-1327

Zhao, Y., Sun, S., Che, H., Guo, Y., Gao, C., 2012. Characteristics of cyclone gasification of rice husk. International Journal of Hydrogen Energy, Volume 37, pp. 16962-16966

\section{NOMENCLATURE}

$\begin{array}{lll}\mathrm{C} & \text { Carbon content }(\%) & \text { AFR }_{\text {act }} \\ \mathrm{H} & \text { Hydrogen content }(\%) & \text { AFR }_{\mathrm{st}} \\ \mathrm{O} & \text { Oxygen content }(\%) & \mathrm{ER} \\ \mathrm{N} & \text { Nitrogen content }(\%) & \mathrm{C}_{\mathrm{p}}(\mathrm{T}) \\ \mathrm{S} & \text { Sulphur content }(\%) & \mathrm{T} \\ \mathrm{P} & \text { Air density }\left(\mathrm{kg} / \mathrm{m}^{3}\right) & \Delta \mathrm{h}_{\mathrm{T}} \\ \mathrm{C}_{\mathrm{d}} & \text { Discharge coefficient } & h_{f}^{o} \\ \mathrm{~A}_{2} & \text { Hole area at orifice plate }\left(\mathrm{m}^{2}\right) & \dot{\mathrm{n}} \\ \mathrm{P}_{1}-\mathrm{P}_{2} & \text { Pressure difference }\left(\mathrm{kg} / \mathrm{m}^{2}\right) & \mathrm{n}_{\mathrm{m}} \\ \mathrm{B} & \text { Pipe to orifice diameter ratio } & \dot{\mathrm{H}} \\ \dot{\mathrm{m}}_{\text {air }} & \text { Mass flow rate of air }(\mathrm{kg} / \mathrm{s}) & \mathrm{H} \\ \dot{\mathrm{m}}_{\text {fuel }} & \text { Feeding rate of fuel }(\mathrm{kg} / \mathrm{s}) & \mathrm{Z} \\ \mathrm{AR} & \text { Air Ratio } & \mathrm{L}\end{array}$

Actual Air to Fuel Ratio

Stoichiometric Air to Fuel Ratio

Equivalence Ratio

Specific heat of gas $(\mathrm{J} / \mathrm{mol} . \mathrm{K})$

Temperature (K)

Change of gas enthalpy $(\mathrm{kJ} / \mathrm{mol})$

Gas formation enthalpy $(\mathrm{kJ} / \mathrm{mol})$

Mol rate of gas $(\mathrm{mol} / \mathrm{s})$

$\mathrm{Mol}$ of gas $/ \mathrm{kg}$ of fuel $(\mathrm{mol} / \mathrm{kg})$

Rate of gas enthalpy $(\mathrm{kJ} / \mathrm{s})$

Gas combustion enthalpy (kJ)

Secondary air injection position (m)

Reactor height (m) 